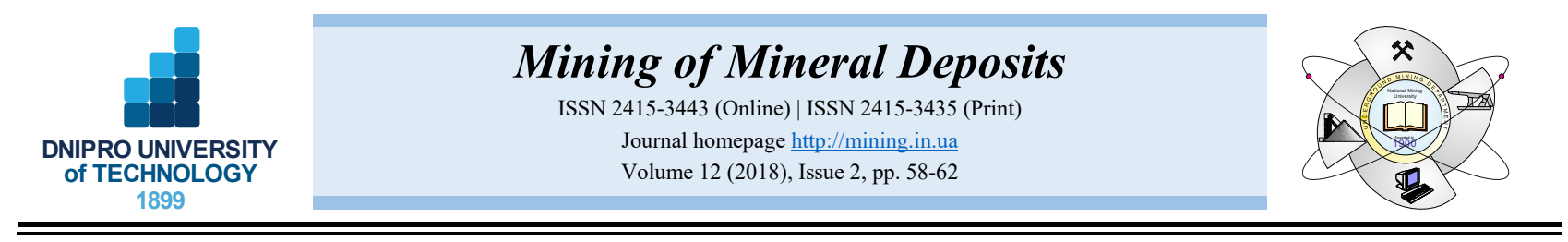

UDC 330.341.1

https://doi.org/10.15407/mining12.02.058

\title{
RESEARCH, SCIENCE, TECHNOLOGY, AND INNOVATION PARKS: REVIEWING BOTH MINING AND RESEARCH TENDENCIES
}

\author{
Z. Tjiparuro ${ }^{1 *}$, O. Kgengwenyane ${ }^{2}$, M. Oageng ${ }^{3}$ \\ ${ }^{1}$ Botswana International University of Science \& Technology, Palapye, Botswana \\ ${ }^{2}$ InnoLead Consulting \& X-Pert Group Botswana, Gaborone, Botswana \\ ${ }^{3}$ Public Procurement \& Asset Disposal Board, Gaborone, Botswana \\ *Corresponding author: e-mail jiparuroz@,biust.ac.bw, tel. +2674922952, fax: +2674900102
}

\begin{abstract}
Purpose. Between 2007 and 2008, a study was undertaken for the Debswana Diamond Company Botswana (Pty) Ltd., a leading diamond mining company in Botswana. The purpose of the study was to establish if Debswana could benefit from participating in a newly established RSTI (research, science, technology, and innovation) park, the Botswana Innovation Hub. Consequently, literature was perused and benchmarking visits undertaken to a RSTI park and three mining councils in South Africa. The decade old study returned a "do-not-participate" finding for the diamond giant. This paper reports these findings and reviews the current situation to see what has changed since 2007 .
\end{abstract}

Methods. A two-pronged approach was used to investigate the extent to which mining companies were participating in RSTI parks. Firstly, a typology of thirty-three (33) keywords was developed and used to do a bibliographic search for articles on the subject matter in scholarly databases such as Web of Science, Scopus, Google Scholar, Mendeley, etc. This was done at the beginning of the study in 2007 and in the current review 10 years later. On the second prong, visits were undertaken to a RSTI park, the Tshwane Innovation Hub, and three (03) mining research councils (i.e. Anglo Research Lab, MINTEK, and DebTech) in South Africa in 2007 and 2008.

Findings. A key notable finding, amongst others, was particularly the fact that these heavy equipment, labour intensive industries did not seem to have any interest in RSTI parks. Moreover, no evidence exist that the world situation has changed since 2017 .

Originality. The study seems to be first of its kind to have investigated the participation of mining industries in RSTI parks. It thus serves as reference for future investigations of the situation.

Practical implications. The paper shares notes distilled from the captains of the South African mining industry and juxtaposes this experience against the RSTI park philosophy. Furthermore, it seeks to ascertain what has changed ever since as vital lessons to other mining consortia elsewhere.

Keywords: research parks, science parks, technology parks, innovation parks, RSTI, diamond, mining

\section{INTRODUCTION}

In today's globalised and knowledge economy, national governments, amongst other, set up estates that host and promote knowledge intensive enterprises. These estates are called science or technology parks hence abbreviated STPs. But other terms are also used such as research parks or innovation hubs, etc., thus leading to many different terminologies (see section 4). Because of these many terminologies, these estates shall be referred to in this paper by the moreencompassing concept of research, science, technology \& innovation, hence RSTI parks hereafter. RSTI parks are not a new idea. The first park was established in 1951 when Stanford University allocated part of its campus leading to the world famed and renowned Silicon Valley. This was followed by the Cambridge Science Park, UK, and Sophia Antipolis, France, in the late 1960s (Bakouros, Mardas, \& Varsakelis, 2002). The whole idea is that spatial closeness between tenants within the park has the desired effect of bringing about an innovative milieu through agglomeration and clustering advantages (Noori, 1998). The same model was later to be replicated around the rest of the world, as a means of wealth creation (Keshmiri, Roustazadeh, Moradi, \& Sadigh, 2005) and economic growth (Ratinho \&

(C) 2018. Z. Tjiparuro, O. Kgengwenyane, M. Oageng. Published by the Dnipro University of Technology on behalf of Mining of Mineral Deposits. This is an Open Access article distributed under the terms of the Creative Commons Attribution License (http://creativecommons.org/licenses/by/4.0/), which permits unrestricted reuse, distribution, and reproduction in any medium, provided the original work is properly cited. 
Henriques, 2010). Wealth and economic derive from the fact that, first and foremost, RSTI parks:

1) nurture the creation and growth of innovation;

2) provide a platform for firms to network;

3) provide a platform for universities to link with firms (Siegel, Westhead, \& Wright, 2003).

In recent years, the world has seen a boom in RSTI parks. By 2015, 117 parks had been established in Africa alone (Kelly, 2015). Certainly, in the list is the Botswana Innovation Hub, established in 2015. Its specific mission was to put Botswana on the world map, as a location for businesses engaged in knowledge intensive activities (The Botswana Innovation Hub, 2016). This came against the back-ground of an economy mired and stuck in one commodity, namely, minerals (a situation often referred to using the common economic moniker of resource-based).

The economy was thus in desperate need of diversification and the government found the idea of science parks a viable proposition. It was not lost on the drafters of the BIH model that meaningful innovation within the realm of knowledge economy should start with the convergence of the main players in the economy (e.g. the mining sector in the case of Botswana) and research institutions. This became the rallying point in the plan.

The Botswana Innovation Hub consequently invited a number of engineering and technology based organizations, amongst them the Debswana Diamond Company Botswana (Pty) Ltd., hereafter Debswana, to set up shop in the science park. It was in this respect that Debswana commissioned the authors through their organizations, namely: X-Pert Group Botswana and the Rural Industries Promotions Company Botswana-RIPCO (B), to undertake a market assessment study. The aim was to establish the areas and conditions under which Debswana could participate in the park. Essentially, could Debswana participate, if so, with who (i.e. alone or with other interest groups)?

This paper reviews and expands the data obtained from a field study conducted between December 2007 and January 2008 in Botswana and South Africa. It was during the course of this study that hard evidence was unearthed about the incompatibility of heavy industry research to RSTI parks. It was particularly noted that this heavy equipment and labour intensive industries did not show interest in RSTI parks anywhere in the world. It was therefore observed with regret that the desire by the BIH to have such heavy industries as tenants was not without challenges. But $2007 / 2008$ is nearly a whole decade ago. Could the situation have changed and if so what has motivated the change? This is the work reported herein, under four sections, starting with section 2 that gives the methodology used and the results obtained. Discussions are in section 3 and finally conclusions are given in section 4 .

\section{METHODOLOGY}

The two methodologies, namely, bibliographic research and industrial survey are discussed below.

\subsection{Bibliographic research}

An effective bibliographic research is dependent on the use of appropriate keywords. In the case of RSTI parks, appropriate keywords were obtained from lists of world RSTI parks compiled by the United Nations Educational, Scientific, and Cultural Organization (UNESCO, 2018). The descriptive phrases such as the "science park" Cambridge Research Park were collated to build a topology of keywords to use. The collated list (e.g. "research park", "science park", etc.) was combined alternately with the three keywords "diamond/mining/mines" (e.g. "research park" and "diamond", "research park" and "mining", "research park" and "mine" etc.) to search for articles that specifically addressed RSTI parks and mining or diamond mines in the Web of Science, Scopus, Google Scholar, and Mendeley. A tally of the hits was recorded and review of the nature of the relationship was also recorded.

\subsection{Benchmarking visits}

Between the 17th to 19th of December 2007, and 21st to 24th of January 2008, visits were undertaken to The Innovation Hub at Tshwane, Anglo Research Lab, DebTech, and MinTek. The purpose of the visits to Anglo Research Lab, DebTech and MinTek were to benchmark and thus inform Debswana on the most ideal form of R \& D practices to adopt in the event that their participation in the Botswana Innovation Hub comes to fruition. Part of observing the R \& D practices at these research institutions, was to establish as to whether the $\mathrm{R} \& \mathrm{D}$ processes at these institutions could easily be accommodated in the innovation hub. On the other hand, the visit to The Innovation Hub was also part of the learning process necessary to inform Debswana on the normal operations that pertain to tenants operating in a science and technology park.

\section{RESULTS}

\subsection{Bibliographic search}

The collated typology of keywords is given in alphabetic order in Table 1.

Table 1. A typology of RSTI parks terms

$\begin{array}{cc}\text { business centre/center } & \text { science city } \\ \text { business cluster } & \text { science hub } \\ \text { business hub } & \text { science parks } \\ \text { business park } & \text { science town } \\ \text { clusters } & \text { startup hub } \\ \text { enterprise zones } & \text { tech park } \\ \text { high tech campus } & \text { technical park } \\ \text { incubator } & \text { technocity } \\ \text { industrial estate } & \text { technology hub } \\ \text { innovation campus } & \text { technology parks } \\ \text { innovation parks/hubs } & \text { technopark } \\ \text { innovation quarter } & \text { technopoles } \\ \text { innovative ecosystem } & \text { technopolis } \\ \text { knowledge park } & \text { teknopark } \\ \text { new technology } & \text { tenant } \\ \text { based firms (NTBFs) } & \\ \text { regional innovation } & \text { venture capital } \\ \text { research parks } & \end{array}$




\subsection{Benchmarking visits}

On the one hand, all three South African Mining Research councils visited (i.e. Anglo Research Lab, DebTech and MinTek) were found to have no RSTI relationship with any RSTI park anywhere in the world. The Tshwane Innovation Hub, on the other hand, did not have any working relationship with any mining institutions anywhere save for Goldfields which was doing research on robotics.

\section{DISCUSSION}

The foregoing results show that the relationship between RSTI parks and mining institutions seems to be nonexistent. Why is this so? The study undertook to find reasons for this situation by looking into the procedures and process of the visited institutions. This is discussed below.

\subsection{RSTI activities}

RSTI activities at Anglo Research Lab, DebTech and MinTek were found to follow the normal protocol that starts with a stated problem through to a seed idea, which through an iterative process of refinement evolves into a product ready for commercialization. A significant reliance on pilot plants was observed. The size and extent of such pilots are real and the space taken up significant. Hence, mining research is without doubt a highly capital intensive process that comes at very high costs.

Moreover, it was observed that RSTI activities in mining are, first and foremost, very much reliant on a network of laboratories (i.e. rock imaging, materials testing, magnetic, environmental, x-ray, process technology, optics, tomography, mineralogy, hydrometallurgy, pyrometallurgy, etc., in a seamless operational layout). Secondly, support services such as CAD laboratories, and workshops (electronics, machining, fabrication, mechatronics, etc.), were always at hand.

It is also important to highlight the fact that the mining RSTI activities present a very "dirty" heavy industry look which may not be aligned to RSTI parks' look and feel. This is particularly relevant in that the $\mathrm{BIH}$ is planning to be a high tech, high value $\mathrm{R} \& \mathrm{D}$ inclined. The Mining $\mathrm{R} \& \mathrm{D}$ sites at MINTEK, DebTech and ARL have a strong industrial look with major implication to health and environment as typically the pilot processes have hazardous effluents and can produce waste that needs to be disposed in an environmentally friendly manner.

\subsection{High caliber personnel}

Given the size and enormity of mining research facilities as discussed above, these facilities need highly qualified staff and a significant number of specialists to manage them. DebTech alone is managed by no less than 64 highly trained engineers, 14 scientists, 27 technicians, 17 artisans and 15 people in administration. On the other hand, the human resources capital of Anglo Research Lab boasts of 218 permanent staff complement of which $16 \%$ are PhD.s, 20\% MSc.s and 46\% BSc.s. Additionally, the research centre has 215 personnel in fixed term contractors of which 115 are skilled. The same pattern, though slightly different and much on the higher side can be found at MinTek. Mintek has about 500 permanent staff members, over half of whom are scientists, engineers and other technical R \& D specialists.

\subsection{Mining as RSTI parks on their own right}

Moreover, it was realized that mining researchers after all organized themselves as RSTI parks on their own right. It was observed that their RSTI operations were reliant on having highly developed engineering and process industries in their vicinity. In Johannesburg where Anglo Research Lab, DebTech and MINTEK are located, their RSTI activities are supported by specialized companies that can support their specialized pilot plants and manufacturing of equipment. This was found to present a challenge for Debswana as there was very little mining engineering and manufacturing capability in Botswana. The R \& D institutions visited exhibited a clear, solid customer base with the critical mass to sustain costs of operations. For instance, Anglo Research Lab caters for the whole of the Anglo mines. DebTech's customer base, on the other hand, includes all De Beers companies egionally and globally, of which Debswana is a part. As for MINTEK its service footprint is also global with Botswana's Tati Nickel Mine a regular customer.

\subsection{Mining as a competitive industry}

Mining is a highly competitive industry with mining houses opting to keep RSTI results in house for secrecy and to ensure that the IP developed only benefits the originator. This could present a challenge for Debswana in inviting other mining companies in Botswana such as Tati Nickel, Muphane Gold, Mmamabula Coal etc. for partnership in the BIH.

\subsection{Peculiarity of diamond research}

When it comes to diamond research, a question was put to DebTech as to why they did not find it attractive to enter collaboration with the rest of mineral research institutions. DebTech's response was that a study they conducted showed that diamond industry is unique and specific, while mineralogy tends to be generic research. The level of overlap between diamond research and other mining research institutions was estimated to be at $20 \%$, a figure which does not give maximum value for a diamond research institute to collaborate with those institutions. It is worth noting that mineral research is a highly competitive environment, where disposition to secrecy is recognized to maintain a competitive advantage. That secrecy is even more profound in the diamond industry. The outcome of DebTech's R \& D process is not licensed off to third parties but is done inhouse and only sub-modules and components get outsourced. Technology that results from their R \& D is not even, and it is strictly prohibited, to be sold outside the DeBeers Group so as to maintain the competitive advantage. The research institute is even wary when it comes to applying for patents, as the fear is that such application may reveal their ingenuity to competitors.

\section{CONCLUSIONS}

In conclusion, it must be noted that the above challenges are profound and real, and need a serious introspection on the side of any mining company that intends to participate in RSTI parks. In fact, when the 
mining institutions were asked as to why they were not anchor tenants in the Tshwane RSTI park or any other elsewhere, it came to pass that most of these research institutions were well established with a long history of existence within which they have established partners, built infrastructure, trained and attracted the best personnel for their operations, and thus expecting them to relocate to seek residence in a science park did not make business sense.

It can be concluded from the foregoing that the direct participation of Debswana in the Botswana Innovation Hub is going to be a first for a mining company, except for the isolated case of Goldfields. The participation of Mining R \& D activities in RSTI parks and Innovation Hubs is not common across the world with most Mining Houses conducting their activities internally. In summary, this study has shown that operating a mining RSTI facility is a very costly process that requires heavy investment in facilities.

The limitation of this study is that the bibliographic search for RSTI parks and mining was done on the basis of published literature in English.

\section{ACKNOWLEDGEMENTS}

This study was made possible through a consultancy paid for by Debswana Diamond Company Botswana (Pty) Ltd., and the authors are deeply thankful to the company for the opportunity.

\section{REFERENCES}

Bakouros, Y.L., Mardas, D.C., \& Varsakelis, N.C. (2002). Science Park, a High Tech Fantasy? An Analysis of the Science Parks of Greece. Technovation, 22(2), 123-128. https://doi.org/10.1016/s0166-4972(00)00087-0

The Botswana Innovation Hub (BIH). (2016). Annual Report. Gaborone, Botswana: Paledi House.

Kelly, T. (2015). Tech Hubs Across Africa: Which Will be the Legacy-Makers? World Bank Information and Communication for Development.

Keshmiri, M., Roustazadeh, E., Moradi, R., \& Sadigh, M.J. (2005). Strong Value-Added Services, Attractions of Technology Parks in Developing Countries. Proceedings of XXI IASP World Conference on Science and Technology Parks, 341-346.

Noori, H. (1998). The Tansition from Low-Valued Repetitive Manufacturing Sites to Technology Hubs: The Influence of Globally Operating Companies. The Journal of High Technology Management Research, 9(1), 69-86. https://doi.org/10.1016/1047-8310(88)90006-5

Siegel, D.S., Westhead, P., \& Wright, M. (2003). Science Parks and the Performance of New Technology-Based Firms: A Review of Recent UK Evidence and an Agenda for Future Research. Small Business Economics, 20(2), 177-184.

Ratinho, T., \& Henriques, E. (2010). The Role of Science Parks and Business Incubators in Converging Countries: Evidence from Portugal. Technovation, 30(4), 278-290. https://doi.org/10.1016/j.technovation.2009.09.002

UNESCO. (2018). Science Policy and Capacity-Building. [online]. Available at: http://www.unesco.org/new/en/natural-sciences/science-technology/university-industry-partnerships/science-parks-around-the-world/science-parks-ineurope/

\section{ПАРКИ НАУКИ, ДОСЛІДЖЕНЬ, ТЕХНІКИ ТА ІННОВАЦІЙ: ОГЛЯД ТЕНДЕНЦІЙ У ГІРНИЧОДОБУВНІЙ ТА ДОСЛІДНІЙ ДІЯЛЬНОСТІ}

\section{3. Тжіпаруро, О. Кженгуеніан, М. Оагінг}

Мета. Визначення доцільності та ефективності участі гірничодобувної компанії Debswana Diamond Company Botswana у створеному парку досліджень, науки, техніки та інновацій (ДНТІ) - Центрі інновацій Ботсвани. У даній статті представлений звіт про результати вивчення питання та огляд поточної ситуації з метою ознайомлення зі змінами після 2007 року.

Методика. Для дослідження того факту, наскільки широко гірничодобувні компанії можуть брати участь у розвитку парків ДНТІ, був застосований двосторонній методичний підхід. По-перше, була розроблена типологія 333 ключових слів; дана типологія була використана для бібліографічного пошуку статей 3 предмету досліджень у таких наукометричних базах даних як Web of Science, Scopus, Google Scholar, Mendeley і т.п. Робота була виконана на початку дослідження у 2007 році; в рамках даного огляду (10 років потому) вона була продовжена. По-друге, у 2007 і 2008 роках були нанесені візити в парк ДНТІ (Інноваційний центр Цване) і три гірничорудні науково-дослідні ради Південно-Африканської Республіки (Anglo Research Lab, MINTEK i DebTech).

Результати. За період 2007 - 2008 років було проведено дослідження для компанії Debswana Diamond Company Botswana (Pty) Ltd., провідної компанії з видобутку алмазів у Ботсвані, щодо визначення найбільш ідеальної форми практики досліджень і розробок, яка буде прийнята у тому випадку, якщо ії участь в Інноваційному центрі Ботсвани буде виправдано і в подальшому реалізовано. Ключовим результатом виконаних досліджень $€$ те, що трудоємні галузі промисловості в загальній тенденції не виявляють жодного інтересу до парків ДНТІ. Більш того, в світовому масштабі через 10 років (з 2017 року) у даній ситуації також не відзначається ніяких змін.

Наукова новизна. Дане дослідження $є$ першим у своєму роді, що звертає пильну увагу на участь гірничодобувних компаній у заснуванні парків ДНТІ. Таким чином, дане дослідження є основою для подальшого вивчення ситуації в більш широких масштабах.

Практична значимість. У даній статті викладаються ідеї, отримані від флагманів гірничодобувної промисловості Південно-Африканської Республіки, у поєднанні з філософією існування парків ДНТІ, а також зміни, що відбулися в системі цих взаємовідносин за останні 10 років. Результати досліджень та досвід створення й функціонування наукових парків корисні для усунення бар'єрів їх розвитку, а також для ознайомлення світовим гірничодобувним концернам.

Ключові слова: парки досліджень, парки науки, парки технологій, парки інновачій, ДНТІ, алмази, гірничі роботи 


\section{ПАРКИ НАУКИ, ИССЛЕДОВАНИЙ, ТЕХНИКИ И ИННОВАЦИЙ: ОБЗОР ТЕНДЕНЦИЙ В ГОРНОДОБЫВАЮЩЕЙ И ИССЛЕДОВАТЕЛЬСКОЙ ДЕЯТЕЛЬНОСТИ}

\section{3. Тжипаруро, О. Кженгуэниан, М. Оагинг}

Цель. Определение целесообразности и эффективности участия горнодобывающей компании Debswana Diamond Company Botswana в созданном парке исследований, науки, техники и инноваций (ИНТИ) - Центре инноваций Ботсваны. В данной статье представлен отчет о результатах изучения вопроса и обзор текущей ситуации с целью ознакомления с изменениями после 2007 года.

Методика. Для исследования того факта, насколько широко горные компании могут участвовать в развитии парков ИНТИ, был применен двусторонний методический подход. Во-первых, была разработана типология из 33 ключевых слов; данная типология была использована для библиографического поиска статей по предмету исследования в таких наукометрических базах данных как Web of Science, Scopus, Google Scholar, Mendeley и т.д. Работа была выполнена в начале исследования в 2007 году; в рамках данного обзора (10 лет спустя) она была продолжена. Во-вторых, в 2007 и 2008 году были нанесены визиты в парк ИНТИ (Инновационный центр Цване) и в три горнорудных научно-исследовательских совета Южно-Африканской Республики (Anglo Research Lab, MINTEK и DebTech).

Результаты. За период 2007 - 2008 годов было проведено исследование для компании Debswana Diamond Company Botswana (Pty) Ltd., ведущей компании по добыче алмазов в Ботсване, по наиболее идеальной форме практики исследований и разработок, которая будет принята в том случае, если их участие в Инновационном центре Ботсваны будет оправдано и в дальнейшем реализовано. Ключевым результатом выполненных исследований является то, что трудоемкие отрасли промышленности в общей тенденции не проявляют никакого интереса к паркам ИНТИ. Более того, в мировом масштабе спустя 10 лет (с 2017 года) в данной ситуации также не отмечается никаких изменений.

Научная новизна. Данное исследование является первым в своем виде, обращающим пристальное внимание на участие горнодобывающих компаний в основании парков ИНТИ. Таким образом, данное исследование является основой для дальнейшего изучения ситуации в более широких масштабах.

Практическая значимость. В данной статье излагаются идеи, полученные от флагманов горнодобывающей промышленности Южно-Африканской Республики, в сочетании с философией существования парков ИНТИ, а также произошедшие изменения в системе этих взаимоотношений за последние 10 лет. Результаты исследований и опыт создания и функционирования научных парков полезны для устранения барьеров их развития, а также для ознакомления ведущим мировым горнодобывающим концернам.

Ключевые слова: парки исследований, парки науки, парки технологий, парки инноваций, ИНТИ, алмазы, горные работь

\section{ARTICLE INFO}

Received: 17 November 2017

Accepted: 23 March 2018

Available online: 31 March 2018

\section{ABOUT AUTHORS}

Zeundjua Tjiparuro, Doctor of Philosophy, Senior Lecturer of the Mechanical and Energy Engineering Department, Botswana International University of Science \& Technology, P.M.B 016, Palapye, Botswana. Email: tjiparuroz@biust.ac.bw

Oabona Kgengwenyane, Master's Degree, Managing Director of the InnoLead Consulting \& X-Pert Group Botswana, Plot 140, Kgale Terrace, Unit 2, Gaborone International Finance Park, P.O BOX 80321, Gaborone, Botswana. E-mail: okgengwenyane@innolead.co.bw

Masego Oageng, Master's of Business Economics, Acting Strategy Manager of the Public Procurement \& Asset Disposal Board, Plot 8913, Maakgadigau Road, Gaborone West Ind. Site, P.M.B 0058, Gaborone, Botswana. E-mail: masmod2000@yahoo.com 